\title{
Comparative use of bacterial, algal and protozoan tests to study toxicity of azo- and anthraquinone dyes
}

\author{
Čeněk Novotný ${ }^{\mathrm{a}, *}$, Nicolina Dias ${ }^{\mathrm{b}}$, Anu Kapanen ${ }^{\mathrm{c}}$, Kateřina Malachová ${ }^{\mathrm{d}}$, \\ Marta Vándrovcová ${ }^{\mathrm{a}}$, Merja Itävaara ${ }^{\mathrm{c}}$, Nelson Lima ${ }^{\mathrm{b}}$ \\ a Laboratory of Experimental Mycology, Institute of Microbiology, Academy of Sciences of the Czech Republic, \\ Vídeňská 1083, 14220 Prague 4, Czech Republic \\ ${ }^{\mathrm{b}}$ Centro de Engenharia Biológica, Universidade do Minho, Campus de Gualtar, 4710-057 Braga, Portugal \\ ${ }^{\mathrm{c}}$ VTT Biotechnology, Tietotie 2, 02044 VTT, Finland \\ ${ }^{\mathrm{d}}$ University of Ostrava, Department of Biology and Ecology, Faculty of Science, 70103 Ostrava 1, Czech Republic
}

Received 25 April 2005; received in revised form 22 September 2005; accepted 2 October 2005

\begin{abstract}
Toxicity of two azo dyes (Reactive Orange 16 (RO16); Congo Red (CR)) and two anthraquinone dyes (Remazol Brilliant Blue R (RBBR); Disperse Blue 3 (DB3)) were compared using bacterium Vibrio fischeri, microalga Selenastrum capricornutum and ciliate Tetrahymena pyriformis. The following respective endpoints were involved: acute toxicity measured as bacterial luminescence inhibition, algal growth inhibition, and the effects on the protozoa including viability, growth inhibition, grazing effect and morphometric effects. In addition, mutagenicity of the dyes was determined using Ames test with bacterium Salmonella typhimurium His ${ }^{-}$. DB3 dye was the most toxic of all dyes in the bacterial, algal and protozoan tests. In contrast to other dyes, DB3 exhibited mutagenic effects after metabolic activation in vitro in all S. typhimurium strains used. Of the methods applied, the algal test was the most sensitive to evaluate toxicity of the dyes tested.
\end{abstract}

(c) 2005 Elsevier Ltd. All rights reserved.

Keywords: Reactive Orange 16; Congo Red; Remazol Brilliant Blue R; Disperse Blue 3; Vibrio fischeri; Selenastrum capricornutum; Tetrahymena pyriformis

\section{Introduction}

Dye production includes thousands of marketed organic colorants used for coloration of textiles, paper, leather, plastics and in specialized applications such as food, drug, cosmetic and photochemical productions (Zollinger, 1987). Azo dyes, widely used in textile indus-

\footnotetext{
${ }^{*}$ Corresponding author. Tel.: +42029644 2357; fax: +420 296442384.

E-mail address: novotny@biomed.cas.cz (Č. Novotný).
}

try, represent the largest and most versatile group whose share in industrial application amounts to some $70 \%$ of all dyestuffs consumed (Ollgaard et al., 1998). Anthraquinone dyes are used for coloration of cotton and cellulose fibres as well as of hydrophobic, synthetic materials (Kirk and Othmer, 1993). During textile processing, as much as $2-50 \%$ of the dyestuff applied may be lost to the wastewater ultimately released into the environment (O’Neill et al., 1999).

Acute toxicity of azo dyes measured by the EU criteria for classification of dangerous substances is rather 
low, amounting to LD50 values of 250-2000 mg per $\mathrm{kg}$ body weight (Clarke and Anliker, 1980). However, their degradation products and impurities include aromatic amines that are compounds of concern due to their potential carcinogenicity. Some acid, basic and direct azo dyes have been classified as acute toxic to toxic to fish, crustaceans, algae and bacteria, whereas reactive azo dyes have very high effective concentration (EC levels $>100 \mathrm{mg}^{-1}$ ) and thus are not considered to be toxic to aquatic organisms. Non-ionic azo dyes are generally classified as toxic and potentially toxic (Ollgaard et al., 1998). Algae are sensitive to dyes but the inhibitory effect is often related to light inhibition at high dye concentrations rather than a direct inhibitory effect of the dyes (Cleuvers et al., 2002).

Much less information is available on toxicity of anthraquinone dyes. Pigment Red 177 classified as an anthraquinone pigment, widely used for coloration of plastics and industrial paints, has been mentioned as not being acutely toxic by the oral route. Its LD50 value exceeded $5000 \mathrm{mg} \mathrm{kg}^{-1}$ (Eurocolour, ETAD, VdMi, 2002).

Correlation between the results of mutagenicity tests and carcinogenicity of azo dyes shown in animal experiments is rather poor. Majority of azo dyes require metabolic activation, namely reduction and cleavage of the azo bond to aromatic amines, to exhibit mutagenicity in in vitro test systems (Arcos and Argus, 1974; Chung, 1983). On the other hand, the correlation between exposure to aromatic amines and human cancer has been well established and documented to be a typical occupational risk (Cartwright, 1983). Mutagenic effect of some textile anthraquinone dyes has been measured using Ames test (Tamaro et al., 1975). Similarly, a carcinogenic effect of the anthraquinone derivative Disperse Blue 1, an agent causing induction of rat bladder tumors, was reported. This compound was also found to be mutagenic in bacteria and thus the possibility of a genotoxic mechanism of cancer induction cannot be excluded (Atkins, 2000).

Reduced exploitation of experimental animals, low cost and rapid performance are the benefits that have made the in vitro toxicity techniques employing microorganisms increasingly used (Olabarrieta et al., 2001; Repetto et al., 2001). Bioluminescence assay with Vibrio fischeri has become broadly used as a fast and reliable preliminary test for risk assessment (Bitton and Koopman, 1992). Selenastrum capricornutum, a most often used algal species, has been found to be sensitive to metals, herbicides and a number of organic chemicals (OECD, 1984; Janssen et al., 2000). This organism is considered to be more sensitive than other standard test organisms to many common compounds (Geis et al., 2000). The potential of ciliates in standard toxicity assays has been demonstrated in aquatic environments (Pauli et al., 1993). Tetrahymena pyriformis is a commonly used ciliated protist with various applicable end- points (Sauvant et al., 1999) A battery of representative toxicological tests including morphological and physiological assays were used to provide complementary information for cytotoxicity on the ciliate $T$. pyriformis (Dias et al., 2003). Ames test with Salmonella typhimurium has been widely used for studying genotoxicity of liquid waste, contaminated soil, sewage sludge and sediments (e.g. Donelly et al., 1991; Malachová, 1999).

The work shows a comparative assessment of toxic effects of two azo- and two anthraquinone dyes using the kinetic modification of the bioluminescence assay with $V$. fischeri (Lappalainen et al., 1999), S. capricornutum test (OECD, 1984) and various T. pyriformis assays (Dias et al., 2003) including a number of different endpoints. The aim was to compare the sensitivity of the individual tests and demonstrate their applicability to the estimation of toxicity of representatives of two major groups of textile dyes. In parallel, genetic toxicity of the dyes was determined using Ames test with and without metabolic activation. The implications for construction of test batteries for the determination of toxicity of industrial dyes and the issuing environmental risks are discussed.

\section{Materials and methods}

\subsection{Toxicity tests}

Kinetic bioluminescence test "flash test". Flash test is a kinetic application of luminescent bacteria test especially tailored for measuring the toxicity of solid and coloured samples (Lappalainen et al., 1999, 2001). Measurement was based on BioTox ${ }^{\mathrm{TM}}$ kit (Aboatox Oy, Finland) utilizing the bacterium $V$. fischeri. Kinetic measurement was performed with a 1251 Luminometer (Bio-Orbit, Turku, Finland) at $20^{\circ} \mathrm{C}$ according to Lappalainen et al. (1999). The exposure times were $30 \mathrm{~s}$ and $30 \mathrm{~min}$, and the peak luminescence value was obtained during the first $5 \mathrm{~s}$ after adding the bacterial suspension to the sample. The tested concentrations amounted to 500-5000 $\mathrm{mg} \mathrm{l}^{-1}$ with RO16, 625-2500 $\mathrm{mg} \mathrm{l}^{-1}$ with CR, 125-2000 mg $1^{-1}$ with RBBR, and 62.5-1000 $\mathrm{mg}^{-1}$ with DB3. The results were calculated as the inhibition $\%$ of light production and expressed using the corresponding EC50 values according to Lappalainen et al. (2001).

Algal test. A standard algal toxicity test (OECD, 1984) on microplates was carried out according to Blaise (1986) . The strain S. capricornutum PRINTZ was obtained from IFA Tulln, Austria. The algal inoculum was cultivated in an incubation chamber $(4000 \mathrm{~lx}$, light/dark cycle $13 / 11 \mathrm{~h}, 24 \pm 2{ }^{\circ} \mathrm{C}$, ATCC No. 625 medium) for four d. Sterile 96-well microtiter plates covered with lids were used to contain (per well): $50 \times$ diluted ATCC No. 625 medium $(5 \mu \mathrm{l})$, sample $(205 \mu \mathrm{l})$ 
algal inoculum $(10 \mu \mathrm{l}$, initial concentration in the well $1 \times 10^{4}$ cells $\mathrm{ml}^{-1}$ ). Distilled water was used as the control. Microplates were incubated in a light chamber and the number of cells counted after 96-h exposure in a light microscope. Each sample was evaluated using 18 replicates and EC50 values were calculated (means \pm confidence interval). Test validity was checked using $\mathrm{K}_{2} \mathrm{Cr}_{2} \mathrm{O}_{7}$, the EC50 values were in the range of $0.2-0.75 \mathrm{mg}^{-1}$.

Protozoan tests. All toxicological assays performed with $T$. pyriformis followed the culture conditions described elsewhere (Dias and Lima, 2002; Dias et al., 2003). Exponentially growing cells were used for inoculation of the individual tests (initial density $1 \times 10^{4}$ cells ml $^{-1}$ ). All dyes were used at a concentration of $500 \mathrm{mg}^{-1}$ and were filtered (pore size $0.45 \mu \mathrm{m}$ ) before adding to the cells. Untreated cells were used as the control in all experiments. Protozoan cells were incubated with the dyes in 2-ml Eppendorf tubes (working volume $1.5 \mathrm{ml}$ ). Samples were removed after a 24-h exposure to check for the toxicity effect. The population growth impairment and generation time determination, grazing assay, and morphometric analysis (cell area and cell width/length $(W / L)$ ratio) were all performed following a procedure described by Dias et al. (2003).

Genetic toxicity test. Standard, quantitative Ames test using variants with and without in vitro metabolic activation with S9 liver microsomal fraction including a cofactor mixture was used. Auxotrophic strains $S$. typhimurium His ${ }^{-}$TA100 and YG1042 were used for the detection of substitute mutations and the strains TA98 and YG1041 for the detection of shift mutations. The mutagenic activity was expressed as a number of revertant colonies $\left(R_{\mathrm{t}}\right)$ related to the total number of colonies in the control sample $\left(R_{\mathrm{c}}\right)$. The increase in the number of revertants was related to the control. The SALM software was used to interpret the results (Margolin et al., 1989; Broekhoven and Nestmann, 1991). The results were compared using the mutagenicity index $\mathrm{IM}=R_{\mathrm{t}} / R_{\mathrm{c}}$ whose twofold increase was considered to be significant (Ames et al., 1975; Maron and Ames, 1983). The mutation potential was expressed by a linear relationship between the dose and the effect $(\mathrm{IM} / c)$. The mutagenicity assessment included at least three replicates where each concentration was represented by two plates. A range including a minimum of five concentrations of the toxicant was used in each test. The results were evaluated using statistical methods to calculate the standard deviation and variation.

\subsection{Chemicals}

Reactive Orange 16 (RO16) (C.I. 17757, monoazo dye), Congo Red (CR) (Direct Red 28, C.I. 22120, disazo dye), Remazol Brilliant Blue R (RBBR) (Reactive Blue 19, C.I. 61200, anthraquinone dye) and Disperse
Blue 3 (DB3) (C.I. 61505, anthraquinone dye) were purchased from Sigma-Aldrich, Germany (cf. Fig. 1). If needed, the dyes were sterilized by filtration. Other chemicals were of analytic grade.

\section{Results}

\subsection{Ecotoxicity tests}

The "flash" bioluminescence test was applicable to the determination of acute toxicity of dark coloured dye solutions. However, the sensitivity to the dyes was low, especially in the case of azo dyes (Table 1). With 30-min exposure time, EC50 values for azo dyes were 1375 and $1623 \mathrm{mg}^{-1}$ for RO16 and CR, respectively. Flash test was more sensitive to anthraquinone dyes, EC50 values for RBBR and DB3 already after $30 \mathrm{~s}$ of exposure were 813 and $359 \mathrm{mg}^{-1}$, respectively. The test organism $V$. fischeri showed two types of response in light inhibition, depending on the tested dye. In the case of DB3 and RO16 dyes, there was practically no difference between the inhibition values observed after $30 \mathrm{~s}$ and $30 \mathrm{~min}$ after application of the toxicant. In contrast, the other two dyes exhibited much higher inhibition after $30 \mathrm{~min}$, probably due to a time period necessary for the toxicant to enter the cell and built up an efficient concentration there.

The algal toxicity test was more sensitive to the dyes, compared to the flash test, with DB3 being the most toxic and RBBR the least toxic of the dyes studied (Table 1). The EC50 value of DB3 of $0.5 \pm 0.0 \mathrm{mg}^{-1}$ was comparable to that of the standard toxicant $\mathrm{K}_{2} \mathrm{Cr}_{2} \mathrm{O}_{7} \quad\left(\mathrm{EC} 50=0.3 \pm 0.1 \mathrm{mg} \mathrm{l}^{-1}\right)$, the EC50 concentrations of the two azo dyes were about tenfold (Table 1).

The results of protozoan tests using 24-h exposure time are summarized in Table 2. The exposure to DB3 increased the mean generation time by about $4 \mathrm{~h}$, whereas RO16, RBBR and CR exhibited no measurable effect. CR and DB3 were able to significantly change the cell area value and $W / L$ ratio, respectively. A decrease in the ingestion capability (grazing) of $T$. pyriformis was found in all treated cultures except for RO16. The greatest effect was observed with DB3, where microsphere ingestion was reduced by $70 \%$, compared to the control.

\subsection{Ames test}

In all tests with and without S9 activation, the dye samples were tested at a dye concentration range of $50-400 \mu \mathrm{g}$ per agar plate, except for the dye DB3. In the case of DB3, where the mutagenic effect was already identified at a dye concentration of $50 \mu \mathrm{g}$ per agar plate, the detection of mutagenicity was carried out in a broader concentration range of $15-520 \mu \mathrm{g}$ per agar 
<smiles>Nc1c(S(=O)(=O)OCCOS(=O)(=O)O[Na])cc(Nc2cccc(S(=O)(=O)O[Na])c2)c2c1C(=O)c1ccccc1C2=O</smiles>

Remazol Brilliant Blue $\mathbf{R}$<smiles>CNc1ccc(NCCO)c2c1C(=O)C1=C(C=CCC=C1)C2=O</smiles>

Disperse Blue 3<smiles>CS(=O)(=O)c1c(N=Nc2ccc(-c3ccc(N=Nc4cc(S(=O)(=O)O)c5ccccc5c4N)cc3)cc2)cc(S(=O)(=O)O)c2ccccc12</smiles>

Congo Red<smiles>CC(=O)Nc1ccc2cc(S(=O)(=O)O)c(N=Nc3ccc(S(=O)(=O)CCOS(=O)(=O)O[Na])cc3)c(O)c2c1</smiles>

Reactive Orange 16

Fig. 1. Chemical structures of the dyes studied.

Table 1

Biological toxicity of dyes measured with bacterial luminescence flash test ( $V$. fischeri) and algal growth inhibition test $(S$. capricornutum)

\begin{tabular}{|c|c|c|c|}
\hline \multirow[t]{3}{*}{ Dye } & \multicolumn{3}{|l|}{ Test } \\
\hline & \multirow{2}{*}{\multicolumn{2}{|c|}{$\begin{array}{l}V . \text { fischeri }^{\mathrm{a}} \\
\text { EC50 values }\left(\mathrm{mg} \mathrm{l}^{-1}\right)\end{array}$}} & \multirow{3}{*}{$\begin{array}{l}\text { S. capricornutum } \\
\text { EC50 values }\left(\mathrm{mg} \mathrm{l}^{-1}\right) \\
96 \mathrm{~h}\end{array}$} \\
\hline & & & \\
\hline Exposure time & $30 \mathrm{~s}$ & $30 \mathrm{~min}$ & \\
\hline Reactive Orange 16 (RO16) & $2430 \pm 17$ & $1375 \pm 46$ & $7.8 \pm 1.8$ \\
\hline Congo Red (CR) & $\mathrm{ND}^{\mathrm{c}} \mathrm{EC} 10=2516 \pm 136$ & $1623 \pm 13$ & $4.8 \pm 1.0$ \\
\hline Remazol Brilliant Blue R (RBBR) & $813 \pm 15$ & $94 \pm 0.5$ & $81.1 \pm 3.5$ \\
\hline Disperse Blue 3 (DB3) & $359 \pm 3$ & $488 \pm 14$ & $0.5 \pm 0.0$ \\
\hline
\end{tabular}

${ }^{\text {a }}$ Mean EC50 \pm standard deviation.

b EC50 value for potassium dichromate was $0.3 \pm 0.1 \mathrm{mg}^{-1}$.

${ }^{\mathrm{c}} \mathrm{ND}$, not determined: $50 \%$ inhibition was not attained up to $2500 \mathrm{mg}$ dye $\mathrm{l}^{-1}$, instead, EC10 value was calculated.

plate, to cover the whole range of linear relationship between the toxicant concentration and the mutagenic effect. A most variable mutagenic effect was detected in the case of RO16 where mutagenicity was observed without metabolic activation in the case of TA98 strain and with metabolic activation in the case of TA98 and 
Table 2

Effect of dye toxicity on generation time, viability, ingestion rate and cell morphology in Tetrahymena pyriformis using 24-h exposure time $^{\text {a }}$

\begin{tabular}{|c|c|c|c|c|c|}
\hline \multirow[t]{2}{*}{ Dye } & \multirow{2}{*}{$\begin{array}{l}\text { Generation } \\
\text { time }(\mathrm{h})\end{array}$} & \multirow{2}{*}{$\begin{array}{l}\text { Viability } \\
\text { (\% of control) }\end{array}$} & \multirow{2}{*}{$\begin{array}{l}\text { Ingestion rate } \\
(\% \text { of control) }\end{array}$} & \multicolumn{2}{|l|}{ Morphometry } \\
\hline & & & & Area $\left(\mu \mathrm{m}^{2}\right)$ & Ratio $(W / L)$ \\
\hline Control & $6.85 \pm 1.59$ & $100 \pm 0.0$ & $100 \pm 0.0$ & $1027 \pm 232$ & $0.414 \pm 0.087$ \\
\hline RO16 & $7.73 \pm 1.25$ & $99.3 \pm 1.0$ & $76.7 \pm 13.5$ & $1093 \pm 249$ & $0.418 \pm 0.091$ \\
\hline $\mathrm{CR}$ & $7.58 \pm 1.46$ & $99.5 \pm 2.4$ & $39.3 \pm 0.0^{\mathrm{b}}$ & $995 \pm 223^{b}$ & $0.426 \pm 0.105$ \\
\hline RBBR & $7.95 \pm 1.95$ & $100.6 \pm 1.0$ & $74.7 \pm 2.6^{\mathrm{b}}$ & $1021 \pm 249$ & $0.431 \pm 0.123$ \\
\hline DB3 & $10.61 \pm 1.17^{\mathrm{b}}$ & $97.0 \pm 3.2$ & $30.5 \pm 5.5^{\mathrm{b}}$ & $1016 \pm 216$ & $0.481 \pm 0.137^{\mathrm{b}}$ \\
\hline
\end{tabular}

${ }^{\mathrm{a}}$ Each value is the mean of two independent assays \pm standard deviation.

${ }^{\mathrm{b}}$ Indicates significant differences from control values $(P<0.01)$.

Table 3

Mutagenic effects of dyes determined with Ames test

\begin{tabular}{lllllllll}
\hline & TA98 & TA98 & TA 100 & TA100 & YG1041 & YG1041 & YG1042 & YG1042 \\
& - S9 & + S9 & - S9 & + S9 & - S9 & + S9 & - S9 & + S9 \\
\hline RO16 & $+0.013^{\mathrm{a}}$ & $+0.013^{\mathrm{a}}$ & - & $+0.006^{\mathrm{a}}$ & - & - & - & - \\
CR & - & - & - & - & - & - & - & - \\
RBBR & - & PM & PM & PM & - & - & - & - \\
DB3 & - & $+0.015^{\mathrm{a}}$ & - & PM & - & $+1.520^{\mathrm{a}}$ & - & $+1.100^{\mathrm{a}}$ \\
\hline
\end{tabular}

Positive effect $(+)$, linear relationship between toxicant concentration and mutagenic effect, more than twofold increase of the number of revertants compared to the control without toxicant; potential mutagenic effect (PM), linear relationship between toxicant concentration and mutagenic effect, less than twofold increase of the number of revertants compared to the control without toxicant; negative effect $(-)$, non-existence of linear relationship between toxicant concentration and mutagenic effect, no increase of the number of revertants compared to the control without toxicant.

a The numbers indicate the value of mutation potential.

TA100 strains (Table 3). DB3 exhibited a toxic effect only after metabolic activation (Table 3). Using DB3 dye, a twofold increase of revertant numbers per plate using the TA98 strain at $50 \mu \mathrm{g}$ dye per plate was observed, whereas 17 -fold and 15-fold increases per plate were observed with the strains YG1041 and YG1042, respectively, at a low concentration of $15 \mu \mathrm{g}$ dye per plate. YG strains were specially developed to detect the mutagenicity of nitroarene compounds and aromatic amines (Hagiwara et al., 1993). RBBR exhibited a potential mutagenic effect, i.e. in dependence on the dye concentration only a smaller than twofold increase in the number of revertants of the indicator strains TA100 and TA98 was measured but a linear relationship between the toxicant concentration and the effect was observed (Table 3 ).

\section{Discussion}

Toxicity of dyes. In spite of different sensitivities of the tests used, the non-reactive, anthraquinone dye DB3 was found to be the most toxic of all dye compounds involved in the study. The corresponding EC50 value detected with $V$. fischeri was more than 500 -fold compared to the alga S. capricornutum. The measured toxicity of DB3 by far exceeded the toxicity of common reactive textile dyes (Heinfling et al., 1997; Wang et al., 2002). A significantly higher toxicity of DB3, compared to the other dyes, was also demonstrated in the growth inhibition-, morphometric- and grazing tests with $T$. pyriformis and the growth inhibition test with $S$. capricornutum. The toxic effects on growth and food ingestion by $T$. pyriformis were very significant as generation time was prolonged almost twofold and the ingestion rate decreased by $70 \%$. Morphometric analysis is suitable to follow the effect of lytic agents that alter cell shape (Dias et al., 2003). The observed $W / L$ ratio increase suggested a rounding off effect on the cells in the presence of DB3 (Kovács et al., 1999). Nevertheless, DB3 did not seem to be a good lytic agent, since less than $10 \%$ of red (non-viable) cells were found after a 24-h exposure.

Sensitivity and expedience of tests. The growth inhibition test with $S$. capricornutum was much more sensitive than the other tests applied. With the algal test, no problems were encountered in measuring EC50 values, in contrast to the traditional, bacterial luminescence test assay (Dodard et al., 1999; Wang et al., 2002). The toxic effects were observed in similar ranges of dye concentrations in the flash luminescence test and protozoan tests, in spite of different endpoints involved. Compared to other compounds, the dyes used were not very efficient in inhibiting luminescence (cf. e.g. El-Alawi et al., 
2002; Peinado et al., 2002). The effective dye concentrations exceeded those normally encountered in textileindustry environmental pollution (Gonçalves et al., 2000). Due to its simplicity and rapidity, the flash test was suitable for determination of toxicity of dye compounds, but its use for toxicity evaluation of dyecontaining diluted effluents could be limited because of the low sensitivity to these compounds.

T. pyriformis was found to be a suitable organism for testing biological toxicity of synthetic dyes. Though not as sensitive as $S$. capricornutum, it clearly demonstrated a higher toxicity of DB3, compared to the other dyes, using different endpoints. In contrast, a tenfold difference in toxicity between RBBR and the azo dyes, observed with the algal test, could not be distinguished with any of the $T$. pyriformis assays. Nor was such a difference indicated by the flash bioluminescence test, where, in contrast, the toxicity of the two azo dyes was significantly lower than that of RBBR. Such differences between the tests probably result from various endpoints involved and reflect different biological complexity of the individual organisms.

Mutagenicity of dyes. RO16 as the only dye tested exhibited mutagenic effects in both the presence and absence of metabolic activation, which indicated that both substitution and frameshift mutations were induced by the compound acting like a direct and indirect mutagen. DB3 showing a mutagenic effect only after the metabolic activation can also be classified as a frameshift mutagen. The positive responses of YG1041 and YG1042 strains observed with the latter dye may have resulted from the presence of methyl and hydroxy ethyl groups in para $(\beta)$ position. The negative results obtained with RBBR and CR could be explained by the presence of sulfonic groups in the dye molecule that can decrease the mutagenic effect (Møller and Wallin, 2000). The fact that mutagenic derivatives could be formed as a result of metabolic conversion indicated that these compounds might represent a health risk for higher organisms including man which had so far been documented for some azo dyes (Møller and Wallin, 2000; Moawad et al., 2003).

The results demonstrate that comparative use of various tests in batteries employing various organisms of different biological complexity is an efficient approach to address the problem of assessment of general toxicity of xenobiotics in risk assessment studies.

\section{Acknowledgements}

The work was supported by the following institutions (projects): GRICES, Portugal/ASCR, Czech Republic (Bilateral Cooperative Project), Grant Agency of the Czech Republic (526/00/1303), Ministry of Education, Youth and Sports of the Czech Republic (LN00b030,
COST 847) and Institutional Research Concept No. AVOZ5020903. The authors thank L. Amaral (Centro de Engenharia Biológica, Universidade do Minho, Braga) for his collaboration in the use of the image analysis software for the morphometric assay, J. Fritz (IFA Tulln) for providing the S. capricornutum strain, and L. Kideryova (Charles University, Prague) for technical assistance.

\section{References}

Ames, B.J.M.C., Cann, J., Yamasaki, R., 1975. Methods for detecting carcinogens and mutagens with the Salmonellal mammalian-microsome mutagenicity test. Mutation Res. 31, 347-364.

Arcos, J.C., Argus, M.F., 1974. Chemical Induction of Cancer: Structural Bases and Biological Mechanisms. Academic Press, New York, p. 249.

Atkins, W.S., 2000. Assessment of the risks to human health posed by certain chemicals in textiles. Final Report, 17th CSTEE Plenary Meeting, Brussels, September 5, 2000.

Bitton, G., Koopman, B., 1992. Bacterial and enzymatic bioassays for toxicity testing in the environment. Res. Environ. Contam. Toxicol. 125, 1-22.

Blaise, C., 1986. Micromethod for acute aquatic toxicity assessment using the green alga Selenastrum capricornutum. Tox. Assess. 1, 377-385.

Broekhoven, L.H., Nestmann, E.R., 1991. Statistical analysis of the Salmonella mutagenicity assay. In: Krewski, D., Franklin, C. (Eds.), Statistics in Toxicology. Gordon and Breach Science Publishers, Amsterdam, The Netherlands, pp. 2834.

Cartwright, R.A., 1983. Historical and modern epidemiological studies on populations exposed to $N$-substituted aryl compounds. Environ. Health Persp. 49, 13-19.

Chung, K-T., 1983. The significance of azo-reduction in the mutagenesis and carcinogenesis of azo dyes. Mutation Res. 114, 269-281.

Clarke, E.A., Anliker, R., 1980. Organic dyes and pigments. In: Handbook of Environmental Chemistry. Springer-Verlag, pp. 181-215.

Cleuvers, M., Altenburger, R., Ratte, H.T., 2002. Combination effect of light and toxicity in algal tests. J. Environ. Quality 31, 539-547.

Dias, N., Lima, N., 2002. A comparative study using a fluorescence-based and a direct-count assay to determine cytotoxicity in Tetrahymena pyriformis. Res. Microbiol. 153, 313-322.

Dias, N., Mortara, R.A., Lima, N., 2003. Morphological and physiological changes in Tetrahymena pyriformis for the in vitro cytotoxicity assessment of Triton X-100. Toxicol. in Vitro 17, 357-366.

Dodard, S.D., Renoux, A.Y., Hawari, J., Ampleman, G., Thiboutot, S., Sunahara, G.I., 1999. Ecotoxicity characterization of dinitrotoluenes and some of their reduced metabolites. Chemosphere 38, 2071-2079.

Donelly, K.C., Brown, K.W., Anderson, C.S., Thomas, C.J., Scott, B.R., 1991. Bacterial mutagenity and acute toxicity of solvent and aqueous extracts of soil samples from a 
chemical manufacturing site. Environ. Toxicol. Chem. 10, $1123-1131$.

El-Alawi, Y.S., McConkey, B.J., Dixon, D.G., Greenberg, B.M., 2002. Measurement of short- and long-term toxicity of polycyclic aromatic hydrocarbons using luminiscent bacteria. Ecotoxicol. Environ. Safe. 51, 12-21.

Eurocolour, Ecological and Toxicological Association of Dyes and Organic Pigments Manufacturers (ETAD), Verband der Mineralfarbenindustrie (VdMi), 2002. Colourants for Food Contact Plastics: Aspects of Product Safety, 4.21 Anthraquinone pigments, p. 49. Available from: <www. cefic.be/files/Publications/FDL_en.pdf $>$.

Geis, S.W., Fleming, K.L., Korthals, E.T., Dearle, G., Reynolds, L., Karner, D.A., 2000. Modifications to the algal growth inhibition test for use as a regulatory assay. Environ. Toxicol. Chem. 19, 36-41.

Gonçalves, I.M.C., Gomes, A., Brás, R., Ferra, M.I.A., Amorim, M.T.P., Porter, R.S., 2000. Biological treatment of effluent containing textile dyes. J. Soc. Dyers Colour. 116 , 393-397.

Hagiwara, Y., Watanabe, M., Oda, Y., Sofuni, T., Nohmi, T., 1993. Specificity and sensitivity of Salmonella typhimurium YG1041 and YG1042 strains possessing elevated levels of both nitroreductase and acetyl transferase activity. Mutation Res. 291, 171-180.

Heinfling, A., Bergbauer, M., Szewzyk, U., 1997. Biodegradation of azo and phthalocyanine dyes by Trametes versicolor and Bjerkandera adusta. Appl. Microbiol. Biotechnol. 48, 261-266.

Janssen, C.R., Vangheluwe, M., VanSprang, P., 2000. A brief review and critical evaluation of the status of microbiotests. In: Persoone, G. et al. (Eds.), New Microbiotests for Routine Toxicity Screening and Biomonitoring. Kluwer Academic/Plenum Publishers, New York, pp. 27-37.

Kirk, R.E., Othmer, D.F., 1993. Dyes, Anthraquinones, fourth ed. In: Kroschwitz, J.I., Howe-Grant, M. (Eds.), KirkOthmer Encyclopedia of Chemical Technology, vol. 8 John Wiley \& Sons, Inc., New York, USA, pp. 653-666.

Kovács, P., Hegyesi, H., Kohidai, L., Nemes, P., Csaba, G., 1999. Effects of C2 ceramide on the inositol phospholipid metabolism (uptake of 32P, 3H-serine and $3 \mathrm{H}$-palmitic acid) and apoptosis-related morphological changes in Tetrahymena. Comp. Biochem. Physiol. 122, 215-224.

Lappalainen, J., Juvonen, R., Vaajasaari, K., Karp, M., 1999. A new flash method for measuring the toxicity of solid and coloured samples. Chemosphere 38, 1069-1083.

Lappalainen, J., Juvonen, R., Nurmi, J., Karp, M., 2001. Automated color correction method for Vibrio fischeri toxicity test. Comparison of standard and kinetic assays. Chemosphere 45, 635-641.

Malachová, K., 1999. Using short-term mutagenicity tests for the evaluation of genotoxicity of contaminated soils. J. Soil Contam. 8, 667-680.
Maron, D.M., Ames, B.N., 1983. Revised methods for the Salmonella mutagenicity test. Mutation Res. 113, 173-215.

Margolin, B.H., Kim, B.S., Risko, K.J., 1989. The Ames Salmonella/microsome mutagenicity assay: issue of inference and validation. J. Am. Stat. Assoc. 84, 651-661.

Moawad, P., Wafaa, M., Abd, El-rahim, Khalafallah, M., 2003. Evaluation of biotoxicity of textile dyes using two bioassays. J. Basic Microbiol. 43, 13-30.

Møller, P., Wallin, H., 2000. Genotoxic hazards of azo pigments and other colorants related to 1-phenylazo-2hydroxynaphthalene. Mutation Res. 462, 13-30.

OECD, 1984. Algal growth inhibition test. OECD Guidelines for Testing Chemicals, No. 201, Organization for Economic Cooperation and Development, Geneva, Switzerland.

Olabarrieta, I., L'Azou, B., Yuric, J., Cambar, J., Cajaraville, M.P., 2001. In vitro effects of cadmium on two different animal cell models. Toxicol. in Vitro 15, 511-517.

Ollgaard, H., Frost, L., Galster, J., Hansen, O.C., 1998. Survey of azo-colorants in Denmark: consumption, use, health and environmental aspects. Ministry of Environment and Energy, Denmark and Danish Environmental Protection Agency, No XX 1998, pp. 147-290.

O'Neill, C., Hawkes, F.R., Hawkes, D.L., Lourenco, N.D., Pinheiro, H.M., Delee, W., 1999. Colour in textile effluents-sources, measurement, discharge consents and simulation: a review. J. Chem. Technol. Biotechnol. 74, 1009-1018.

Pauli, W., Berger, S., Jaskulka, L., Schmitz, S., 1993. A case for the inclusion of a protozoan test in aquatic toxicity assessment using Tetrahymena. Sci. Total Environ. Suppl., 779-786.

Peinado, M.T., Mariscal, A., Carnero-Varo, M., FernándezCrehuet, J., 2002. Correlation of two bioluminescence and one fluorogenic bioassay for the detection of toxic chemicals. Ecotoxicol. Environ. Safe. 53, 170-177.

Repetto, G., Jos, A., Hazen, M.J., Molero, M.L., Del Peso, A., Salguero, M., Del Castillo, P., Rodriguez-Vicente, M.C., Repetto, M., 2001. A test battery for the ecotoxicological evaluation of pentachlorophenol. Toxicol. in Vitro 15, 503509 .

Sauvant, M.P., Pepin, D., Piccinni, E., 1999. Tetrahymena pyriformis: a tool for toxicological studies. A review. Chemosphere 38, 1631-1669.

Tamaro, M., Monti-Bragadin, C., Banfi, E., 1975. Mutagenic activity of anthraquinone derivatives used as dyes in a textile factory. Boll. Ist. Sieroter. Milan 26, 105-107.

Wang, C., Yediler, A., Lienert, D., Wang, Z., Kettrup, R., 2002. Toxicity evaluation of reactive dyestuffs, auxiliaries and selected effluents in textile finishing industry to luminescent bacteria Vibrio fischeri. Chemosphere 46, 339-344.

Zollinger, H., 1987. Colour Chemistry-Synthesis, Properties and Applications of Organic Dyes and Pigments. VCH, New York, pp. 92-100. 